\title{
Perbaikan Pakan pada Induk Sapi Perah sedang Laktasi di Kabupaten Enrekang, Sulawesi Selatan
}

\author{
(Feed Improvement on the Lactating Dairy Cows in Enrekang, South Sulawesi)
}

\author{
Nurhayu A, Ella A, Sariubang M \\ Balai Pengkajian Teknologi Pertanian Sulawesi Selatan, Jl. Perintis Kemerdekaan km 17,5 Makassar \\ a_nurhayu@yahoo.com
}

\begin{abstract}
The research was conducted in of Tanete village, Anggeraja sub district, Enrekang district South Sulawesi. The objective of this research was to determine the effect of feed improvement to increase milk production of lactating dairy cow. This research was carried out with a completely randomized design using 12 lactating dairy cows which divided into 3 treatments with 4 replications: (A) $60 \%$ of elephant grass $+30 \%$ corn straw $+10 \%$ local formula concentrate; (B) $30 \%$ of elephant grass $+60 \%$ corn straw $+10 \%$ local formula concentrate; and (C) Controls. The results showed that milk production obtained during the feeding period reached the highest improvement in treatment B and A with an average milk production of 7.66 and 6.90 1/cow/day respectively. The lowest one was $\mathrm{C}$ (control) that produved $4.90 \mathrm{l} / \mathrm{cow} / \mathrm{day}$. The analysis of farming showed that treatment $\mathrm{B}$ had the highest profit (Rp. 6,778/cow/day), followed by the treatment A (Rp. 3,962/cow/day) and the treatment C (Rp 1,030/cow/day). It can be concluded that feed improvement in lactating dairy cows with grass, fermented corn straw and the addition of concentrates was good combination to increase milk production in lactating dairy cows.
\end{abstract}

Key Words: Lactating Dairy Cows, Feed, Milk Production

\begin{abstract}
ABSTRAK
Kajian dilaksanakan di Kelurahan Tanete Kecamatan Anggeraja, Kabupaten Enrekang, Sulawesi Selatan. Tujuan dari kajian ini adalah untuk mengetahui pengaruh perbaikan pakan terhadap peningkatan produksi susu induk sapi perah sedang laktasi. Kajian dilakukan dengan rancangan acak lengkap menggunakan 12 ekor induk sapi perah sedang laktasi dibagi dalam 3 perlakuan dengan 4 ulangan yaitu: (A) $60 \%$ rumput Gajah $+30 \%$ jerami jagung $+10 \%$ konsentrat formula lokal; (B) 30\% rumput Gajah $+60 \%$ jerami jagung $+10 \%$ konsentrat formula lokal; dan (C) Kontrol. Hasil kajian menunjukkan produksi susu yang diperoleh selama periode perbaikan pakan adalah tertinggi pada perlakuan B dan A dengan rata-rata produksi susu sebesar 6,90-7,66 1/ekor/hari serta terendah adalah perlakuan C (kontrol) sebesar 4,90 l/ekor/hari. Analisis usaha tani menunjukkan bahwa perlakuan $\mathrm{B}$ memberikan keuntungan yang paling tinggi (Rp. 6.778/ekor/hari), diikuti perlakuan A (Rp. 3.962/ekor/hari) dan perlakuan C (Rp. 1.030/ekor/hari). Dapat disimpulkan bahwa perbaikan pakan pada induk sapi perah sedang laktasi melalui pemberian rumput yang dikombinasi dengan jerami jagung fermentasi serta penambahan pakan penguat konsentrat sangat baik untuk meningkatkan produksi susu pada induk sapi perah sedang laktasi.
\end{abstract}

Kata Kunci: Induk Sapi Laktasi, Pakan, Produksi Susu

\section{PENDAHULUAN}

Dalam usaha peternakan sapi perah, memperoleh produksi susu yang tinggi dan berkesinambungan merupakan suatu hal yang didambakan oleh setiap peternak. Saat ini, produksi susu di Indonesia masih sangat rendah, produksi susu sapi perah yang dihasilkan hanya sebesar 6-10 1/ekor/hari, padahal idealnya menghasilkan 15-20 1/ekor/hari (Sunu et al. 2008). Pada tahun 2016 Indonesia memiliki populasi sapi perah sebanyak 533.860 ekor 
dengan pasokan susu segar yang dihasilkan sejumlah 341.986 ton/tahun. Dengan kebutuhan susu dalam negeri sebesar 1.427.000 ton, Indonesia masih harus mengimpor susu sebesar 1.085.014 ton (Ahmad et al. 2008). Di Sulawesi Selatan, populasi sapi perah mencapai 1.553 ekor dengan populasi tertinggi di Kabupaten Enrekang sebesar 696 ekor (BPS Provinsi Sulawesi Selatan 2015).

Rendahnya produksi susu di Indonesia khususnya di Sulawesi Selatan disebabkan oleh beberapa faktor penentu dalam usaha peternakan yaitu pemuliaan dan reproduksi, penyediaan dan pemberian pakan, pemeliharaan ternak, penyediaan sarana dan prasarana, serta pencegahan penyakit dan pengobatan. Manajemen pakan memiliki proporsi sebesar tujuh puluh persen dalam produktivitas susu, dan sisanya adalah breeding dan manajemen kandang (Hartutik 2009).

Kendala yang sering dijumpai pada usaha pemberian pakan pada sapi perah yaitu ketersediaan pakan. Ketersediaan hijauan tidak mencukupi kebutuhan ternak disebabkan semakin sempitnya lahan penggembalan yang banyak dikonversi menjadi lahan-lahan pertanian bahkan perumahan. Selain itu, pada musim kemarau tingkat produksi hijauan akan rendah, atau bahkan dapat berkurang sama sekali. Peranan pakan sangat penting khususnya untuk induk sapi perah karena pakan merupakan salah satu sumber pendukung meningkatnya tampilan produksi dan kadar lemak susu. Penambahan mutu pakan dengan perbandingan hijauan dan konsentrat yang seimbang akan memberikan tampilan produksi dan kadar lemak susu yang bagus (Setyaningsih et al. 2013).

Di pihak lain, produk samping/ikutan tanaman berupa limbah berpotensi untuk diolah menjadi pakan ternak. Meningkatnya intensifikasi tanaman pangan mengakibatkan peningkatan produksi limbah tanaman yang dapat dimanfaatkan sebagai sumber pakan. Pengembangan industri sapi perah mempunyai prospek yang sangat baik dengan memanfaatkan sumberdaya lahan maupun sumberdaya pakan (limbah pertanian dan perkebunan) (Pomolango et al. 2016).

Peranan induk-induk yang berkemampuan repoduksi tinggi adalah cukup penting, meskipun performa produksi susu mempunyai heritabilitas yang rendah. Sapi perah laktasi terlebih yang berproduksi tinggi, memerlukan nutrien yang cukup memadai baik kuantitas maupun kualitasnya. Tujuan kajian ini adalah untuk mengetahui pengaruh perbaikan pakan terhadap peningkatan produksi susu induk sapi perah sedang laktasi.

\section{MATERI DAN METODE}

Penelitian dilaksanakan di Kelurahan Tanete, Kecamatan Anggeraja, Kabupaten Enrekang, Sulawesi Selatan. Kegiatan penelitian menggunakan 12 ekor induk sapi perah sedang laktasi dengan rata-rata bobot badan $400 \mathrm{~kg}$, umur 3-4 tahun, status laktasi 2-3 periode. Dibagi dalam 3 perlakuan dengan 4 ulangan yaitu: Perlakuan A: 60\% rumput gajah $+30 \%$ jerami jagung fermentasi $+10 \%$ konsentrat formula lokal; Perlakuan B: $30 \%$ rumput gajah $+60 \%$ jerami jagung fermentasi $+10 \%$ konsentrat formula lokal; dan Perlakuan C: Kontrol (sesuai kebiasan petani).

Limbah jerami jagung terlebih dahulu difermentasi dengan menggunakan decomposer selama 21 hari. Proses fermentasi adalah tahap pertama jerami jagung yang baru panen (kandungan air sekitar 65\%) dipotong kecil-kecil, setelah itu dikumpulkan pada tempat yang tersedia. Jerami jagung ditumpuk hingga ketebalan $\pm 20 \mathrm{~cm}$, kemudian ditaburi urea dan dekomposer dan diteruskan pada lapisan timbunan jerami berikutnya hingga mencapai 1-2 m. Takaran urea dan probiotik masing-masing $6 \mathrm{~kg}$ untuk setiap ton jerami jagung segar. Pencampuran urea dan probiotik pada jerami dilakukan secara merata, kemudian didiamkan selama 21 hari. 
Untuk pakan tambahan berupa konsentrat berbahan baku lokal dapat dilihat pada Tabel 1. Pengamatan dilakukan selama empat bulan. Data yang diperoleh dianalisis dengan menggunakan Rancangan Acak Lengkap (RAL) dengan uji lanjut beda nyata terkecil. Parameter yang dikumpulkan adalah produksi susu, konsumsi pakan dan analisis usaha tani.

Tabel 1. Komposisi bahan pakan konsentrat

\begin{tabular}{lc}
\hline \hline Bahan pakan & Komposisi $(\%)$ \\
\hline Dedak & 43,0 \\
Bungkil kelapa & 20,0 \\
Tepung ikan & 20,0 \\
Jagung giling & 15,0 \\
Garam & 0,5 \\
Mineral & 0,5 \\
Molases & 1,0 \\
\hline Jumlah & 100,0 \\
\hline
\end{tabular}

\section{HASIL DAN PEMBAHASAN}

\section{Jenis dan jumlah pemberian pakan}

Hijauan yang diberikan adalah rumput gajah yang banyak terdapat di sekitar kandang di lokasi pengkajian. Selain itu, pemanfaatan limbah jerami/batang jagung banyak terdapat di lokasi pengkajian untuk memenuhi kebutuhan ternak akan hijauan. Pakan tambahan berupa konsentrat berdasarkan komposisi untuk induk sapi perah laktasi dengan kandungan protein sebesar 19\%. Pemberian konsentrat adalah untuk memenuhi kebutuhan protein induk sapi perah laktasi. Kualitas dari konsentrat dan hijauan yang diberikan disajikan pada Tabel 2.

Tabel 2. Kandungan nutrisi pakan untuk induk laktasi sapi perah di Enrekang, 2016

\begin{tabular}{lcccc}
\hline \hline \multirow{2}{*}{ Jenis } & Protein kasar & Serat kasar & Lemak kasar & \begin{tabular}{c} 
ME \\
\cline { 2 - 3 }
\end{tabular} \\
\cline { 2 - 3 } (kkal/kg BK)
\end{tabular}

Sumber: Laboratorium Tanah Maros (2016)

Berdasarkan Tabel 2, jerami jagung yang telah difermentasi kandungan protein kasarnya sebesar 7,82\%, SK sebesar 20,89\% dan lemak kasar sebesar 2,44\%. Kandungan protein kasar jerami jagung sebelum difermentasi adalah 4,77\%; serat kasar 30,53\%; dan lemak kasar 1,06\% (Nursiam 2010). Pada Tabel 3 terlihat kandungan protein kasar perlakuan yang tertinggi adalah A sebesar $10,14 \%$ dan terendah adalah $\mathrm{C}$ sebesar 7,54\%. Meningkatnya kandungan protein kasar serta menurunnya nilai serat kasar akan lebih memudahkan ternak untuk mencerna jerami jagung. Seperti yang dikemukakan oleh Martawidjaya (2003) bahwa kandungan protein yang rendah dan serat kasar yang tinggi penyebab rendahnya daya cerna menjadi faktor pembatas dari pemanfaatan jerami sebagai pakan ruminansia. 
Tabel 3. Kandungan nutrisi pakan perlakuan untuk induk laktasi sapi perah di Enrekang, 2016

\begin{tabular}{lccc}
\hline \hline \multirow{2}{*}{ Jenis } & \multicolumn{3}{c}{ Perlakuan } \\
\cline { 2 - 4 } & $\mathrm{A}$ & $\mathrm{B}$ & $\mathrm{C}$ \\
\hline Rumput Gajah/alam (\%) & 60,00 & 30,00 & 99,00 \\
Jerami jagung (\%) & 30,00 & 60,00 & - \\
Konsentrat (\%) & 10,00 & 10,00 & - \\
Dedak & 0 & 0 & 1 \\
Komposisi pakan (\%)* & & & 7,54 \\
Protein kasar (\%) & 10,14 & 9,50 & 23,00 \\
Serat kasar (\%) & 24,76 & 22,07 & 5,54 \\
Lemak kasar (\%) & 2,84 & 2,74 & \\
\hline
\end{tabular}

*Dihitung berdasarkan Tabel 2

Pakan konsentrat sebagaimana tertera pada Tabel 2, telah sesuai kualitasnya untuk sapi-sapi perah yang berproduksi susu tinggi. Konsentrat yang diberikan mempunyai kandungan PK sebesar 19,04\% lebih tinggi dari yang telah direkomendasikan. Para pakar nutrisi sapi perah merekomendasikan, bahwa kualitas pakan konsentrat untuk sapi-sapi perah yang berproduksi susu tinggi minimal mengandung $18 \%$ protein kasar dan $75 \%$ TDN atau sekitar 4,75 Mkal/kg bahan kering (Siregar 1996). Kandungan energi yang diberikan sebesar $2.629 \mathrm{kkal} / \mathrm{kg}$ lebih rendah dari yang direkomendasikan sebesar 4.750 $\mathrm{kkal} / \mathrm{kg}$. Tingginya pemberian pakan berenergi menyebabkan peningkatan konsumsi dan daya cerna dari rumput atau hijauan kualitas rendah. Penambahan konsentrat tertentu dapat juga bertujuan agar zat makanan lebih mudah diserap di usus tanpa terfermentasi di rumen, mengingat fermentasi rumen membutuhkan energi lebih banyak.

\section{Konsumsi pakan dan produksi susu}

Di samping kualitas, jumlah pakan yang diberikan untuk tiap ekor/hari perlu pula diketahui agar kebutuhan zat gizi untuk mencapai kemampuan berproduksi susu yang tinggi terpenuhi. Jumlah konsentrat yang diberikan untuk tiap ekor/hari ternyata habis dikonsumsi oleh masing-masing sapi perah yang digunakan sebagai materi penelitian ini. Sementara itu, hijauan yang diberikan setiap harinya masih ada sisa. Rata-rata pakan konsentrat dan hijauan yang mampu dikonsumsi oleh setiap ekor sapi setiap harinya dapat dilihat pada Tabel 3 .

Tabel 4. Konsumsi pakan konsentrat dan hijauan pada sapi perah di Enrekang, 2016

\begin{tabular}{lccc}
\hline \hline \multirow{2}{*}{ Jenis pakan } & \multicolumn{3}{c}{ Perlakuan(kg/ekor/hari) } \\
\cline { 2 - 4 } & $\mathrm{A}$ & $\mathrm{B}$ & $\mathrm{C}$ \\
\hline Konsumsi BK & & & \\
Rumput Gajah & 4,30 & 2,20 & 6,80 \\
Jerami jagung fermentasi & 2,08 & 4,10 & - \\
Konsentrat & 1,14 & 1,12 & - \\
Dedak & 0,00 & 0,00 & 1,10 \\
\hline Jumlah & 7,52 & 7,42 & 7,80 \\
\hline
\end{tabular}

Hasil analisis statistik menunjukkan bahwa pemberian rumput Gajah dan jerami jagung (A dan B) menghasilkan konsumsi bahan kering yang tidak berbeda nyata $(\mathrm{P}>0,05)$ dengan kontrol yaitu 7,52 dan 7,42 vs $7,8 \mathrm{~kg}$. Konsumsi pakan tidak menunjukkan 
perbedaan nyata pada semua perlakuan. Hal ini menunjukkan bahwa penambahan jerami jagung tidak berpengaruh terhadap peningkatan konsumsi bahan kering. Jumlah konsumsi pada perlakuan $\mathrm{A}, \mathrm{B}$ dan $\mathrm{C}$ agak rendah, karena dengan rataan bobot badan ketiga perlakuan sebesar $388 \mathrm{~kg}$ seharusnya bisa mengkonsumsi pakan dalam bentuk bahan kering sebanyak $9,7 \mathrm{~kg}$ atau 2,5\% dari bobot badan (Preston \& Leng 1987). Dengan demikian, sapi-sapi tersebut mengalami kekurangan pakan sekitar 1-2 kg bahan kering atau sekitar 0,1-0,2\% dari bobot badannya. Imbangan rumput gajah dan konsentrat perlu diperhatikan pada induk sapi perah agar gizi ternak berimbang sehingga zat-zat makanan dapat dicerna, difermentasi dan diabsorbsi dengan baik untuk keperluan produksi secara maksimal (Musnandar 2011).

Tabel 5 menunjukkan rata-rata produksi susu yang diperoleh selama periode perbaikan pakan adalah tertinggi pada perlakuan B dengan rata-rata produksi susu yang tidak berbeda dengan perlakuan $\mathrm{A}$ dan terendah adalah perlakuan $\mathrm{C}$ (kontrol) yang hanya diberi rumput dan dedak sebesar 4,90 liter/ekor/hari. Hasil uji lanjut menunjukkan, produksi susu perlakuan A dan B tidak berbeda nyata $(\mathrm{P}>0,05)$ kemungkinan disebabkan jumlah pakan yang dikonsumsi tidak terlalu beda, demikian pula dengan kandungan nutrisi pakannya. Penambahan konsentrat yang dikosumsi sebesar 1,1 kg BK disertai pemberian rumput dan subtitusi jerami jagung fermentasi berdampak besar terhadap peningkatan kemampuan berproduksi susu sapi-sapi perah di lokasi pelaksanaan kajian. Adanya peningkatan kemampuan berproduksi susu tersebut sekaligus juga mengungkapkan, bahwa potensi genetik dalam berproduksi susu dari sapi-sapi perah induk di lokasi penelitian masih dapat ditingkatkan melalui perbaikan pakan (kuantitas dan kualitas). Hal ini sesuai dengan pendapat Reist et al. (2000) bahwa status nutrisi pada sapi perah mempengaruhi produksi yang dihasilkannya. Sapi yang mempunyai produksi susu tinggi akan membutuhkan energi hidup pokok untuk fungsi jaringan tubuh dan produksi yang melebihi dari energi yang dapat dikonsumsinya.

Tabel 5. Produksi susu sapi selama periode perbaikan pakan di Enrekang, 2016

\begin{tabular}{lccc}
\hline \hline \multirow{2}{*}{ Periode laktasi (bulan) } & \multicolumn{3}{c}{ Perlakuan (1/ekor/hari) } \\
\cline { 2 - 4 } & A & B & C \\
\hline 1 & 5,97 & 7,19 & 4,00 \\
2 & 7,47 & 8,10 & 5,50 \\
3 & 7,32 & 8,02 & 5,55 \\
4 & 6,84 & 7,33 & 4,55 \\
\hline Rata-rata & $6,90^{\mathrm{b}}$ & $7,66^{\mathrm{b}}$ & $4,90^{\mathrm{a}}$ \\
\hline
\end{tabular}

Periode laktasi pada semua perlakuan mencapai puncaknya pada periode laktasi ke-2 dan 3. Pada periode laktasi ke-4, terjadi penurunan produksi susu pada semua perlakuan. Kondisi produksi susu mencapai puncak pada periode ke-2 laktasi sesuai yang dikemukakan oleh Siregar (1993) bahwa dari sejak melahirkan, produksi susu akan meningkat dengan cepat sampai mencapai puncak produksi pada 35-50 hari setelah melahirkan. Setelah mencapai puncak produksi, produksi susu harian akan mengalami penurunan. Hal ini juga sejalan dengan penelitian Hadisutanto et al. (2013) mengungkapkan bahwa puncak laktasi dicapai pada periode laktasi kedua dan ketiga, di mana periode laktasi I memiliki kemampuan menghasilkan rataan produksi susu lebih rendah dari periode laktasi II dan III. Adanya perbedaan produksi susu yang dihasilkan disebabkan karena tingkat kebutuhan dari induk sapi perah yang pertama kali melahirkan (primipara) dan induk sapi perah yang melahirkan lebih dari satu kali (pluripara) yang berbeda. 


\section{Analisis usaha tani}

Analisis usaha tani pada induk sapi perah sedang laktasi dengan perlakuan perbaikan pakan yaitu pemberian hijauan rumput Gajah disubtitusi dengan jerami jagung fermentasi serta penambahan pakan penguat konsentrat, dapat dilihat pada Tabel 6 berikut.

Tabel 6. Analisis usaha sapi induk laktasi di Enrekang, 2016

\begin{tabular}{lccc}
\hline \hline \multirow{2}{*}{ Uraian } & \multicolumn{3}{c}{ Perlakuan } \\
\cline { 2 - 4 } & $\mathrm{A}$ & $\mathrm{B}$ & $\mathrm{C}$ \\
\hline Bobot badan awal (kg) & 380 & 378 & 382 \\
Bobot badan akhir (kg) & 389 & 394 & 385 \\
PBB (g/ekor/hari) & 75 & 133 & 25 \\
Jumlah pengeluaran (Rp/ekor/hari) & 28.466 & 29.216 & 22.000 \\
Produksi susu rata-rata (1) & & & \\
Harian (1 ekor/hari) & 6,90 & 7,66 & 4,90 \\
Jumlah penerimaan & $32.484,04$ & $35.993,19$ & $23.030,0$ \\
\hline Keuntungan (Rp/ekor/hari) & 3.962 & 6.778 & 1.030 \\
\hline R/C ratio & 1,14 & 1,23 & 1,05 \\
\hline
\end{tabular}

Rumput: Rp. 500/kg; Jerami jagung fermentasi: Rp. 600/kg; Konsentrat: Rp. 3.020/kg; Dedak: Rp. 2500/kg; harga estimasi

Tujuan utama dalam pembukaan usaha yang direncanakan adalah keuntungan. Menurut Prawirokusumo (1990), keuntungan adalah jumlah rupiah yang didapat dari pendapatan bersih suatu usaha. Keuntungan merupakan selisih antara penerimaan total dengan biaya (biaya tetap dan biaya tidak tetap). Usaha sapi perah petani layak diusahakan dan menguntungkan dengan nilai R/C perlakuan A sebesar 1,14, perlakuan B sebesar 1,23 dan perlakuan $\mathrm{C}$ sebesar 1,05, yang artinya lebih dari satu, ketika $\mathrm{R} / \mathrm{C}$ lebih dari satu maka usaha tersebut dikatakan untung.

\section{KESIMPULAN}

Perbaikan pakan pada induk sapi perah sedang laktasi dengan pemberian rumput serta penambahan jerami jagung fermentasi dan penambahan pakan penguat konsentrat mampu meningkatkan produksi susu pada induk sapi perah sedang laktasi. Pemberian 30\% rumput Gajah $+60 \%$ jerami jagung fermentasi $+10 \%$ konsentrat memberikan keuntungan tertinggi.

\section{UCAPAN TERIMA KASIH}

Penulis mengucapkan terima kasih kepada Bapak Kepala Dinas Peternakan, penyuluh serta kelompok tani di Kabupaten Enrekang yang telah bekerjasama dan memberikan bantuan selama berlangsungnya kegiatan kajian.

\section{DAFTAR PUSTAKA}

Ahmad I, Hermiyeti. 2008. Analisis produksi dan konsumsi susu di Indonesia. Dalam: Diwyanto K, Wina E, Priyanti A, Natalia L, Herawati T, Purwandaya B, penyunting. Prosiding Prospek 
Industri Sapi Perah Menuju Perdagangan Bebas 2020. Jakarta, 21 April 2008. Bogor (Indonesia): Puslitbangnak dan STEKPI. hlm. 413-419.

BPS Provinsi Sulawesi Selatan. 2015. Sulawesi Selatan dalam angka. Makassar (Indonesia): Badan Pusat Statistik Provinsi Sulawesi Selatan.

Hadisutanto B, Purwantara B, Darodjah S. 2013. Involusi uteri dan waktu estrus pada induk sapi perah FH pasca partus. J Ilmu Ternak. 13:4-7.

Hartutik. 2009. Strategi manajemen pemberian pakan dalam upaya peningkatan produktivitas sapi perah rakyat. Pidato Pengukuhan Guru Besar. Malang (Indonesia): Universitas Brawijaya.

Martawidjaya M. 2003. Pemanfaatan jerami padi sebagai pengganti rumput untuk ternak ruminansia kecil. Wartazoa. 13:120-121.

Musnandar C. 2011. Efisiensi energi pada sapi perah Holstein yang diberi berbagai imbangan rumput dan konsentrat. J Penelitian Universitas Jambi Seri Sains. 13:53-58.

Nursiam I. 2010. Bahan makanan ternak, limbah pertanian. [Internet]. Available from: https://intannursiam.wordpress.com.

Pomolango R, Kaunang ChL, Elly FH. 2016. Analisis produksi limbah tanaman pangan sebagai pakan ternak sapi di Kabupaten Bolaang Mongondow Utara. J Zootek. 36:302-311.

Prawirokusumo S. 1990. Ilmu usaha tani. Yogyakarta (Indonesia): BIEP.

Preston TR, Leng RA. 1987. Matching ruminant production system with avalilable resources in the tropics and sub-tropics. New South Wales (Australia).

Reist M, Koller A, Busato A, Kupfer U, Blum JW. 2000. First ovulation and ketone body status in the early postpartum period of dairy cows. Theriogenology. 54:685-701.

Setyaningsih W. Budiarti C, Suparyogi TH. 2013. Peran massage dan pakan terhadap produksi dan kadar lemak susu kambing Peranakan Ettawah. Anim Agric. 2:329-335.

Siregar SB. 2008. Penggemukan sapi. Jakarta (Indonesia): Penebar Swadaya.

Sunu KPW, Hartutik, Hermanto. 2008. Pengaruh penggunaan ajitein pakan terhadap produksi dan kualitas sapu perah. J Ilmu-ilmu Peternakan. 23:42-51. 